\title{
Stimulation of Selected Cellulases from Trichoderma reesei with White Linearly Polarized Light
}

\author{
Ewelina Nowak', Gohar Khachatryan ${ }^{1}$, Agnieszka Polit ${ }^{2}$, Lidia Krzeminska-Fiedorowicz ${ }^{1}$, \\ Marta Dziedzicka-Wasylewska ${ }^{2}$, Maciej Fiedorowicz ${ }^{1^{*}}$ \\ ${ }^{1}$ Department of Chemistry and Physics, University of Agriculture, Krakow, Poland \\ ${ }^{2}$ Faculty of Biochemistry, Biophysics and Biotechnology, Jagiellonian University, Krakow, Poland \\ Email: ${ }^{*}$ rrfiedor@cyf-kr.edu.pl
}

Received April 17, 2012; revised May 23, 2012; accepted June 4, 2012

\begin{abstract}
The impact of the illumination with white linearly polarized light (WLPL) of two commercially available cellulases from Trichoderma reesei on their activity in hydrolysis of microcrystalline cellulose was studied. Enzymes were illuminated with WLPL for 60 min and 120 min and for each native and illuminated enzyme sample specific activity and kinetics of enzyme catalyzed hydrolysis of microcrystalline cellulose were established. Molecular weight $\mathrm{M}_{\mathrm{w}}$ and radii if gyration $\mathrm{R}_{\mathrm{g}}$ of protein chains of native and illuminated enzymes were measured by means of high pressure size exclusion chromatography coupled with multiangle laser light scattering and refractometric detectors (HPSEC-MALLS-RI). Conformations of protein chains of native and illuminated enzymes were evaluated on the basis of their circular dichroism (CD) spectra. Additionally, molecular weight $\mathrm{M}_{\mathrm{w}}$ and radii of gyration $\mathrm{R}_{\mathrm{g}}$ of polysaccharide chains of microcrystalline cellulose native and digested for $10 \mathrm{~min}, 480 \mathrm{~min}$ and $1440 \mathrm{~min}$ with original and WLPL stimulated enzymes WT and TR were taken. Illumination with WLPL of both cellulases studied did not change secondary structures of protein molecules of native enzyme. Molecular weight $\mathrm{M}_{\mathrm{w}}$ and radii of gyration $\mathrm{R}_{\mathrm{g}}$ of illuminated enzymes differed greatly from those found for native enzymes. Illumination of enzymes led to increase of specific activity and rate constants of reaction of hydrolysis microcrystalline cellulose catalyzed by illuminated enzymes as compared with native enzymes.
\end{abstract}

Keywords: Cellulases; Polarized Light; Microcrystalline Cellulose

\section{Introduction}

Cellulose is the most abundant and renewable resource of the biosphere. Degradation of cellulose, particularly that enzymatic, to soluble sugars for fuels and industrially essential chemicals has been expected to solve problems of the energy shortage and, at the same time, environment protection. Thus far, combustion of wood is a principal way of the cellulose utilization.

Low specific activity and high cost of polysaccharide hydrolyzing enzymes [1-3] are the main limiting factors in industrial hydrolysis of biomass containing cellulose. Therefore, attempting to introduce efficient enzymes is well rationalized. Hydrolysis of crystalline cellulose is the rate-limiting step in the biomass conversion to ethanol because aqueous enzyme solutions cannot access the contact with active centers of this insoluble, highly ordered structure. In the rate-limiting step disruption of a single substrate chain from its native matrix takes place instead of catalytic cleavage of the hydrolysis of the material, thereby rendering it accessible to the catalytically

\footnotetext{
${ }^{*}$ Corresponding author.
}

active cellulase site. Understanding cellulase structure function relationships [4] is one of the key problems of successful implementation of novel enzymes. Similarly, understanding of microcrystalline cellulose molecular structure and interactions between polysaccharide chain with enzyme proteins will allow tailoring enzymes of improved hydrolytic properties.

In the last 20 years, white linearly polarized light (WLPL) has found many applications in medicine. Medical cases being treated with polarized light include severe second degree burns [5,6], wound healing [7], leg ulcers, psoriasis and egzema $[8,9]$. The biostimulating action of low-energy laser light, which is widely used in medicine, could be attributed to the polarization of the laser light [10]. Recently a stimulating influence of white linearly polarized light (WLPL) on enzymes belonging to hydrolyases family i.e. $\alpha$-amylase in starch $\alpha$-amylolysis [11], xylanase in degradation of xylan [12], chitinase and chitosanase in degradation of chitin and chitosan [13] was reported. It was shown that WLPL action also stimulates catalytic activity of cyclodextrin glucosyltransferase [14] and glucose oxidase [15] belonging to 
cyclase and oxidase families respectively. The mechanisms of the enzyme activity enhancement with WLPL is unknown. It has been demonstrated [11] that $1 \mathrm{hr}$ illumination with WLPL of $\alpha$-amylase solutions led to statistically significant changes in the protein conformation of illuminated enzyme, accompanied by acceleration of the potato starch hydrolysis catalyzed by the activated enzyme. Such results indicate that the enhancement of the activity of WLPL stimulated enzymes could be related to conformational changes of the protein molecules.

In this study this problem is approached by examination of the effect of illumination with WLPL of two commercially available cellulases, isolated from different microorganisms. This effect is checked involving kinetics of the hydrolysis of microcrystalline cellulose catalysed with so stimulated enzymes. Absolute molecular weight and conformation of protein chains of native and illuminated enzymes was also compared. Additionally, changes of molecular weight of cellulose chains in the course of enzymatic degradation were recorded, to check the enzyme source and/or WLPL stimulation have any impact upon the molecular structure of enzymatically degraded polysaccharide chains.

\section{Experimental}

\subsection{Materials}

Cellulase (TR) isolated from Trichoderma reesei (EC 3.2.1.4) in aqueous solution (TR) and as a solid powder (WT) was purchased from Sigma (Poznań, Poland) and Worthington Biochemical Corporation (Lakewood NJ, USA), respectively.

Microcrystalline cellulose and N,N-dimethylacetamide (DMAc, HPLC grade) was purchased from Sigma, Poznan, Poland.

\subsection{Stimulation of the Enzymes by WLPL Illumination}

Cellulase WT batch solution was prepared by dissolving $20 \mathrm{mg}$ solid enzyme in $20 \mathrm{ml}$ acetate buffer $(\mathrm{pH}=5)$. In the case of cellulase TR $2 \mathrm{ml}$ aliquot of original enzyme preparation was dissolved in $18 \mathrm{ml} \mathrm{pH} 5$ acetate buffer. Solutions of both enzymes were divided into three $6 \mathrm{ml}$ samples. One sample of each enzyme solution was stored in the dark, whereas the other samples were placed in the glass cells and illuminated with WLPL for 60 and 120 min respectively. Samples were illuminated from the 30 $\mathrm{cm}$ distance with a KB 502 slit illuminator (Kabid, Chorzów, Poland) equipped with $150 \mathrm{~W}$ xenon arc (XBO 150. Oriel, Maidstone, UK). An HN 22 linear polarizing filter (Polaroid, Waltham MA, USA) with a glass filter cutting off wavelengths below $500 \mathrm{~nm}$ was mounted between the slit illuminator and the sample. The light source emitted continuous radiation in the visible range. Its energy flux at the position of the sample was 8 $\mathrm{mW} / \mathrm{cm}^{2}$ as checked by YSI radiometer (Yellow Springs, $\mathrm{OH}$, USA). During the illumination temperature in the place of the samples was controlled and did not exceeded $20^{\circ} \mathrm{C}$. Immediately after termination of the illumination specific activity of each enzyme sample was measured.

\subsection{Determination of Specific Activity of Native and WLPL Stimulated Enzymes}

Specific activity of enzymes prior to and after WLPL illumination was determined by its effect on microcrystalline cellulose with respect to glucose formation. Released glucose was determined in a hexokinase/glucose-6phosphate dehydrogenase system at $340 \mathrm{~nm}$ using Glucose (HK) Assay Kit (SIGMA, Poznan, Poland) employing procedure reported elsewhere [16]. One unit of activity releases $0.01 \mathrm{mg}$ glucose per hour from microcrystalline cellulose at $37^{\circ} \mathrm{C}$.

\subsection{Enzymatic Hydrolysis of Microcrystalline Cellulose Catalyzed by Native and Illuminated Enzymes}

Cellulose samples $(800 \mathrm{mg}$ ) were exactly weighed in Erlenmeyer flasks and suspended in acetate buffer $(\mathrm{pH}=$ $5,38 \mathrm{ml}$ ). Erlenmeyer flasks containing cellulose suspensions were placed in water bath for $5 \mathrm{~min}$ at $37^{\circ} \mathrm{C}$, than aliquots $(2 \mathrm{ml})$ of native and WLPL illuminated solutions of respective enzymes were added and reaction mixtures were incubated in a shaking water bath. In the specified time intervals $0.4 \mathrm{ml}$ aliquots were removed from the reaction mixture, centrifuged at $8000 \mathrm{rpm}$ for 10 min and supernatants were diluted with deionized water to obtain final sample volume $(2 \mathrm{ml})$. In each sample reducing sugars were determined by the DNS method [16].

\subsection{Determination of Molecular Weight $\left(\mathrm{M}_{\mathrm{w}}\right)$ and Radii of Gyration $\left(R_{g}\right)$ of, Native and Enzymatically Digested Microcrystalline Cellulose Chains}

\subsubsection{Sample Preparation for Chromatographic Assay}

Microcrystalline cellulose samples were dissolved in 8\% $\mathrm{LiCl} / \mathrm{DMac}$ by slightly modified method described elsewhere $[17,18]$. Thus, $4 \times 10^{-2} \mathrm{~g}$ cellulose was placed in $10 \mathrm{ml}$ measuring flask then cellulose was activated by two consecutive swellings in $10 \mathrm{ml}$ deionised water at $40^{\circ} \mathrm{C}$, for $8 \mathrm{hr}$, followed by two consecutive transfers of the samples into $8 \mathrm{ml}$ methanol for $45 \mathrm{~min}$ and finally into two consecutive transfers into $8 \mathrm{ml}$ DMAc for $12 \mathrm{hr}$. After each exchange, solvent was removed by vacuum filtra- 
tion. After the last DMAc exchange $10 \mathrm{ml}$ of $8 \% \mathrm{LiCl} /$ DMAc was added to the sample. The samples were stirred initially at room temperature for $24 \mathrm{hr}$, than stirring continued at $4^{\circ} \mathrm{C}$ up to complete dissolution ( 2 to 3 days). After dissolution $2 \mathrm{ml}$ aliquots were taken for chromatographic analysis, diluted to $20 \mathrm{ml}$ volume with $\mathrm{LiCl} /$ DMAc and filtered thorough a $0.5 \mu \mathrm{m}$ pore PTFE filter (Whatman, England) prior to the injection.

\subsubsection{Enzyme Digested Cellulose Samples}

Aliquots $(2 \mathrm{ml})$ of the reaction mixture were collected at time intervals (10 min, $8 \mathrm{hr}, 24 \mathrm{hr}$ ), placed in boiled water bath for $5 \mathrm{~min}$, than centrifuged from denatured enzyme protein. Supernatant was slowly evaporated to dryness at $60^{\circ} \mathrm{C}$ and resulted solid was dissolved in the same manner as native microcrystalline cellulose, omitting step of the cellulose activation by solvent exchange with water and methanol.

Before analysis each sample was diluted to $20 \mathrm{ml}$ volume with $\mathrm{LiCl} / \mathrm{DMAc}$ and filtered thorough a $0.5 \mu \mathrm{m}$ pore PTFE filter (Whatman, England).

Anhydrous DMAc, carefully dried over aluminium sodium silicate molecular sieve, $0.4 \mathrm{~nm}$ effective pore size (Fisher Scientific, Springfield, NJ, USA), was used for activation, and for the preparation of the dissolution solvent and SEC mobile phase. $\mathrm{LiCl}$ was oven dried and, prior to use, stored in desiccator in pre-weighted amounts.

\subsubsection{High Performance Size Exclusion Chromatography (HPSEC-MALLS-RI)}

The high performance size exclusion chromatography (HPSEC) system for determination of average molecular weight and radii of gyration of native and digested microcrystalline cellulose chains consisted of a pump (Shimadzu 10AC, Tokyo, Japan), an injection valve with $500 \mu$ loop (model 7021, Rheodyne, Palo Alto, CA, USA), a SDV guard column $(50 \times 8 \mathrm{~mm}, 20 \mu \mathrm{m}$, PSS, Mainz, Germany), and two connected size exclusion columns SDV $(300 \times 8 \mathrm{~mm}, 20 \mu \mathrm{m}$, PSS, Mainz, Germany) and SDV Linear XL $(600 \times 8 \mathrm{~mm}, 10 \mu \mathrm{m}$, PSS, Mainz, Germany). The columns were placed in a thermostated column compartment and the system was operated at $60^{\circ} \mathrm{C}$. A multiangle laser light scattering detector (MALLS) operating in chromatographic mode using a He-Ne laser light source (630.0 nm) (Dawn-DSP-F, Wyatt Technology, Santa Barbara, CA, USA) and a differential refractive index detector (L-7490, Merck, Darmstadt, Germany) were connected to the columns. The mobile phase $(0.5 \% \mathrm{LiCl} / \mathrm{DMAc})$ was filtered through 0.2 $\mu \mathrm{m}$ PTFE (Whatman, England) and vacuum degassed. The flow rate of the mobile phase and the sample injection volume were $1.0 \mathrm{ml} / \mathrm{min}$ and $500 \mu \mathrm{l}$, respectively. The output voltage of refractive index (RI) and light scattering (LS) at 18 angles was used for calculation of the weight-average molecular weight $\left(\mathrm{M}_{\mathrm{w}}\right)$ and radius of gyration $\left(\mathrm{R}_{\mathrm{g}}\right)$ using Astra 4.73.04 software (Wyatt Technology, Santa Barbara, CA, USA). In calculations of $\mathrm{M}_{\mathrm{w}}$ and $R_{g} \mathrm{dn} / \mathrm{dc}$ value $0.077(\mathrm{ml} / \mathrm{g})$ for cellulose [19] was applied.

The Berry plot with third order polynomial fit was applied in the calculation of $\mathrm{M}_{\mathrm{w}}$ and $\mathrm{R}_{\mathrm{g}}$ values. Separations were run in duplicates.

\subsection{Determination of Molecular Weight $\left(\mathrm{M}_{\mathrm{w}}\right)$ and Radii of Gyration $\left(R_{g}\right)$ of Enzyme Protein Chains.}

Average molecular weight $\left(\mathrm{M}_{\mathrm{w}}\right)$ and radii of gyration $\left(\mathrm{R}_{\mathrm{g}}\right)$ of original and illuminated enzyme protein chains were determined using HPSEC-MALLS-RI system described in previous section.

The separation was carried out on a set of two connected size exclusion columns TSKgel GMPWXL $(300 \times$ $7.8 \mathrm{~mm}$, Tosoh Corporation, Tokyo, Japan) and TSKgel 2500 PWXL $(300 \times 7.8 \mathrm{~mm}$, Tosoh Corporation, Tokyo, Japan). The columns and the refractive index detector were maintained at $25^{\circ} \mathrm{C}$. The mobile phase $(0.15 \mathrm{M}$ $\mathrm{NaNO}_{3}$ with $0.02 \%$ sodium azide) was filtered through 0.2 and $0.1 \mu \mathrm{m}$ cellulose acetate filters (Whatman, England) and vacuum degassed. The flow rate of the mobile phase and the sample injection volume were $0.4 \mathrm{ml} / \mathrm{min}^{-1}$ and $500 \mu \mathrm{l}$ respectively. Prior to injection, the batch solutions of original and illuminated enzymes were filtered through a $0.5 \mu \mathrm{m}$ pore cellulose acetate filter (Whatman, England).

\subsection{Evaluation of Protein Conformation of Enzymes Cd Spectra}

Circular dichroism spectra of the WT and TR cellulase solutions kept in the dark and illuminated for $1 \mathrm{~h}$ and $2 \mathrm{~h}$ with visible nonpolarized and linearly polarized light were recorded using a JASCO J-710 (Jasco, Japan) spectrophotometer (upgraded to a J-715).

\section{Sample Preparation}

Water batch solutions $(30 \mathrm{ml})$ of each enzyme at concentration of $2 \mathrm{mg} / \mathrm{ml}$ were divided into 3 parts. One sample was stored in the dark. Two other samples of each enzyme were illuminated with WLPL for $1 \mathrm{~h}$ and $2 \mathrm{~h}$, respectively, under conditions described above. Immediately after termination of illuminations samples were dialyzed and protein concentration in each sample was determined. Samples were diluted with water to obtain final protein concentration of $0.7 \mathrm{mg} / \mathrm{ml}$. For evaluation of the secondary protein structure, CD spectra of each enzyme sample were recorded in the range of $250-190$ $\mathrm{nm}$ using quartz cylindrical cells with the 1 of $0.2 \mathrm{~mm}$ optical path and scanning speed $20 \mathrm{~nm} / \mathrm{min}$. Subse- 
quently, in order to evaluate the tertiary protein structure, spectra were recorded in the range of 350 - $250 \mathrm{~nm}$ using a quartz cylindrical $1 \mathrm{~cm}$ optical path cell. Each spectrum was the average of three scans with the average buffer control spectrum subtracted. Data obtained were not smoothed. Proteins secondary structure content was performed with 1.51 Spectra Manager software using reference set containing five proteins: hemoglobin, lysozyme, myoglobin, ribonuclease $\mathrm{A}$ and $\alpha$-chymotripsin $\mathrm{A}$.

\section{Results and Discussion}

Specific activity of WT and TR enzymes, original and WLPL illuminated for 60 (WT60, TR60) and $120 \mathrm{~min}$ (WT120, TR120) are presented in Table 1.

Specific activity of enzyme WT illuminated with WLPL for $60 \mathrm{~min}$ was slightly, although statistically significantly, higher, than activity of original enzyme. Prolonged (120 min) illumination of this sample led to further, more pronounced, increase in the enzyme specific activity. In the case of enzyme TR, Illumination with WLPL for $60 \mathrm{~min}$ did not change specific activity of TR enzyme. However, its illumination for $120 \mathrm{~min}$ led to significant increase in its specific activity.

Hydrolysis kinetics curves of microcrystalline cellulose digested by solutions of non-illuminated and WLPL illuminated enzymes WT and TR are presented in Figures 1(a) and (b) respectively.

Enzymes degrading carbohydrate polymers can follow three fundamentally different mechanisms [20]. They are 1) a multiple chain mechanism, where the enzyme-substrate complex dissociates after each reaction; 2) a single-chain mechanism, where the enzyme remains associated with the substrate until every cleavage-plaint linkage in the chain hydrolyzes; and 3) a multiple attack mechanism, where a given average number of attacks were performed after the formation of the enzyme-substrate complex. As it can be seen in Figures 1(a) and (b), the degradation of cellulose by original and illuminated enzymes follows two rate laws.

Rate constants for both stages of enzymatic degradation of cellulose with native and WLPL stimulated enzymes WT and TR are given in Table 2 Illumination of enzyme WT with WLPL for $60 \mathrm{~min}$ led to slight, al though statistically significant rise of the rate constant for the first stage of cellulose degradation. Rate constant for the first step of the cellulose hydrolysis catalyzed by WT illuminated for 120 min remained unchanged. In the case of enzyme TR, illumination with WLPL for $120 \mathrm{~min}$ led to significant rise of rate constant of the first stage of the cellulose degradation.

In the case of the second, much slower stage of the cellulose degradation, illumination of both WT and TR enzymes with WLPL for $120 \mathrm{~min}$ led to a rise of $\mathrm{k}_{2}$ rate constant. Acceleration of the second step of the cellulose deg- radation was much more pronounced in the case of enzyme WT stimulated with WLPL for $120 \mathrm{~min}$ as compared to similarly treated enzyme TR.

In order to check whether stimulation of cellulases by means of illumination with WLPL have any impact on molecular structure of cellulose chains in the course of hydrolysis average molecular weight $\left(\mathrm{M}_{\mathrm{w}}\right)$ and radii of gyration $\left(\mathrm{R}_{\mathrm{g}}\right)$ of microcrystalline cellulose chains native and digested for $10 \mathrm{~min}, 480 \mathrm{~min}$ and $1440 \mathrm{~min}$ with original and WLPL stimulated enzymes WT and TR were taken. Measurements were performed for the material eluted under whole polysaccharide peak from HPLC column (Table 3).

Table 1. Specific activity of enzymes WT and TR prior to and after illumination with the WLPL ${ }^{\mathrm{a}}$.

\begin{tabular}{ccc}
\hline \multirow{2}{*}{$\begin{array}{c}\text { Enzyme illumination time } \\
{[\mathrm{min}]}\end{array}$} & \multicolumn{2}{c}{ Enzyme specific activity } \\
\cline { 2 - 3 } & WT $[\mathrm{u} / \mathrm{mg}]$ & $\mathrm{TR}[\mathrm{u} / \mathrm{ml}]$ \\
\hline 0 & $65.0 \pm 0.6$ & $820.1 \pm 10.0$ \\
60 & $68.3 \pm 0.8$ & $823.0 \pm 9.1$ \\
120 & $73.4 \pm 0.9$ & $1166.6 \pm 10.1$ \\
\hline
\end{tabular}

${ }^{\mathrm{a}}$ Means of three independent experiments \pm standard deviation.

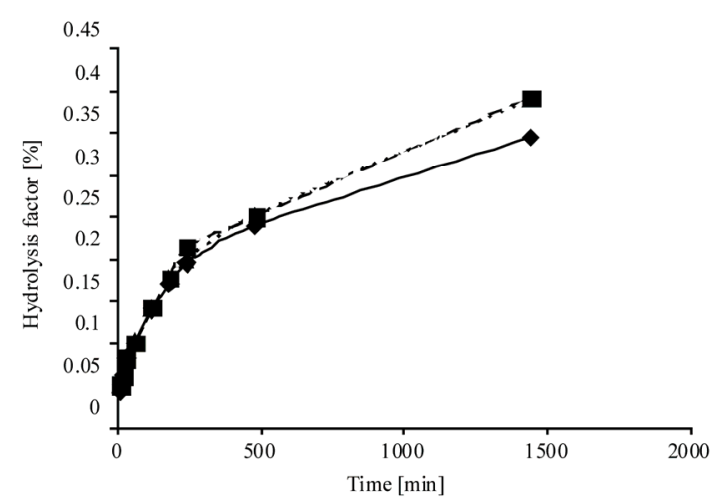

(a)

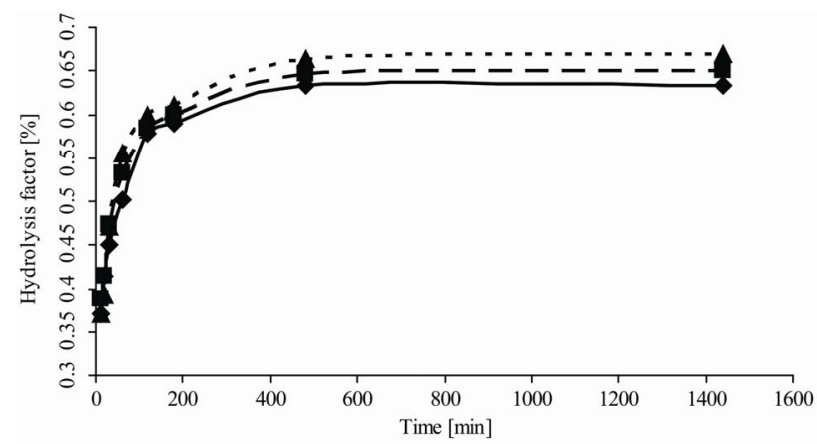

(b)

Figure 1. (a) Kinetics of the microcrystalline cellulose hydrolysis with enzyme WT; (b) Kinetics of the microcrystalline cellulose hydrolysis with enzyme TR. Samples of enzymes native (४) and illuminated with WLPL for $60 \mathrm{~min}($ (a) and $120 \mathrm{~min}(\Delta)$. 
Table 2. Rate constants of the enzymatic degradation of cellulose with enzymes WT and TR prior to and after their stimulation with WLPL ${ }^{\mathrm{a}}$.

\begin{tabular}{ccc}
\hline Sample $^{\mathrm{a}}$ & $\mathrm{k}_{1} \times 10^{-4}\left[\mathrm{mg} / \mathrm{mL}^{-1} / \mathrm{min}^{-1}\right]$ & $\mathrm{k}_{2} \times 10^{-5}\left[\mathrm{mg} / \mathrm{mL}^{-1} / \mathrm{min}^{-1}\right]$ \\
\hline WT & $2.60 \pm 0.20$ & $4.34 \pm 0.21$ \\
WT 60 & $3.00 \pm 0.15$ & $4.34 \pm 0.32$ \\
WT 120 & $2.60 \pm 0.15$ & $8.68 \pm 0.34$ \\
TR & $7.81 \pm 0.20$ & $1.30 \pm 0.13$ \\
TR 60 & $7.38 \pm 0.20$ & $1.30 \pm 0.12$ \\
TR 120 & $9.12 \pm 0.18$ & $1.74 \pm 0.21$ \\
\hline
\end{tabular}

${ }^{\mathrm{a}}$ Means of three independent experiments \pm standard deviation.

Molecular weight of polysaccharides digested for 10 min by original enzymes WT and TR slightly declined. The same effect was noted for the cellulose molecules digested for 10 min by WT and TR enzymes stimulated with WLPL for $60 \mathrm{~min}$. However, average molecular weight of cellulose chains digested 10 min by WT and TR illuminated with WLPL for $120 \mathrm{~min}$ decreased significantly to $1.58 \times 10^{6}$ and $1.57 \times 10^{6}$, respectively. Calculated average molecular weight of cellulose chains left non-digested in the reaction mixture after $480 \mathrm{~min}$ of the hydrolysis differed greatly, depending of the enzyme origin and time of their stimulation with WLPL. Sharp reduction of average molecular weight of the cellulose polysaccharide chains digested for 480 min by original WT $(0.761$ $\left.\times 10^{6}\right)$, WT60 $\left(0.550 \times 10^{6}\right)$ and WT120 $\min \left(0.148 \times 10^{6}\right)$ could be noted. Likely, original and WLPL stimulated enzyme in the first stage of the reaction, hydrolyzed mainly long cellulose chains of high molecular weight. In contrast to it, average molecular weight of polysaccharide chains digested for $480 \mathrm{~min}$ by original enzyme TR $(2.56$ $\times 10^{6}$ ) was slightly lower than molecular weight observed for cellulose molecules digested by this enzyme for $10 \mathrm{~min}$ $\left(2.88 \times 10^{6}\right)$. Possibly, mainly shorter cellulose chains were attacked by original enzyme TR in the first stage of hydrolysis. Similarly, such assumption could explain that in the reaction catalyzed by TR $120\left(1.99 \times 10^{6}\right)$ average molecular weight of non-digested cellulose molecules was higher in the reaction mixture hydrolyzed for $480 \mathrm{~min}$ than in the reaction mixture digested for $10 \mathrm{~min}$. Interestingly, the 60 min stimulation with WLPL led to significant decrease in the average molecular weight of cellulose chains left in the reaction mixture after 480 min digestion by TR60 $\left(0.330 \times 10^{6}\right)$. Average molecular weight of cellulose chains remaining in the reaction mixture after completing hydrolysis within 1440 min were much higher than molecular weight of polysaccharide chains left after 480 min digestion for all original and WLPL enzymes studied. It could indicate that in the second stage of hydrolysis enzymes digested mainly short cellulose chains. Molecular weight of original and WLPL stimulated enzymes WT and TR are presented in Table 4 and results of evaluation of the enzymes protein secondary conformation are summarized in Table 5.

Table 3. Average molecular weight $M_{w}$ and radii of gyration $R_{g}$ of the cellulose chains hydrolyzed by native and illuminated with WLPL enzymes WT and TR prior to and after stimulation with WLPL. ${ }^{a}$

\begin{tabular}{|c|c|c|c|c|c|c|c|c|}
\hline \multirow{4}{*}{ Sample ${ }^{\mathrm{b}}$} & \multicolumn{8}{|c|}{ Average molecular weight $\left(\mathrm{M}_{\mathrm{w}}\right)$ and radii of gyration $\left(\mathrm{R}_{\mathrm{g}}\right)$ of enzyme digested cellulose chains } \\
\hline & \multicolumn{8}{|c|}{$\begin{array}{l}\text { Hydrolysis time } \\
\text { [min] }\end{array}$} \\
\hline & \multicolumn{2}{|c|}{0} & \multicolumn{2}{|c|}{10} & \multicolumn{2}{|c|}{480} & \multicolumn{2}{|c|}{1440} \\
\hline & $\mathrm{M}_{\mathrm{W}} \times 10^{6}$ & $\mathrm{R}_{\mathrm{g}}[\mathrm{nm}]$ & $\mathrm{M}_{\mathrm{W}} \times 10^{6}$ & $\mathrm{R}_{\mathrm{g}}[\mathrm{nm}]$ & $\mathrm{M}_{\mathrm{W}} \times 10^{6}$ & $\mathrm{R}_{\mathrm{g}}[\mathrm{nm}]$ & $\mathrm{M}_{\mathrm{W}} \times 10^{6}$ & $\mathrm{R}_{\mathrm{g}}[\mathrm{nm}]$ \\
\hline WT native & $2.99 \pm 0.104$ & $80.15 \pm 5.15$ & $2.65 \pm 0.105$ & $59.7 \pm 4.5$ & $0.761 \pm 0.050$ & $42.7 \pm 3.1$ & $0.855 \pm 0.025$ & $93.1 \pm 3.1$ \\
\hline WT 60 & $2.99 \pm 0.104$ & $80.1 \pm 5.15$ & $2.67 \pm 0.099$ & $40.0 \pm 5.0$ & $0.550 \pm 0.034$ & $47.7 \pm 3.4$ & $1.35 \pm 0.034$ & $59.1 \pm 5.0$ \\
\hline WT 120 & $2.99 \pm 0.104$ & $80.1 \pm 5.15$ & $1.58 \pm 0.099$ & $103.8 \pm 5.1$ & $0.148 \pm 0.040$ & $54.4 \pm 2.5$ & $1.99 \pm 0.099$ & $39.8 \pm 4.5$ \\
\hline TR native & $2.99 \pm 0.104$ & $80.1 \pm 5.15$ & $2.88 \pm 0.100$ & $78.3 \pm 5.5$ & $2.56 \pm 0.099$ & $56.3 \pm 3.3$ & $1.61 \pm 0.87$ & $50.8 \pm 4.1$ \\
\hline TR 60 & $2.99 \pm 0.104$ & $80.1 \pm 5.15$ & $2.19 \pm 0.102$ & $42.1 \pm 4.1$ & $0.355 \pm 0.020$ & $47.8 \pm 2.6$ & $2.45 \pm 0.099$ & $50.2 \pm 2.1$ \\
\hline TR 120 & $2.99 \pm 0.104$ & $80.1 \pm 5.15$ & $1.57 \pm 0.080$ & $40.6 \pm 3.9$ & $1.99 \pm 0.058$ & $54.4 \pm 3.2$ & $2.52 \pm 0.105$ & $52.8 \pm 2.3$ \\
\hline
\end{tabular}

${ }^{\mathrm{a}}$ Means of three independent experiments \pm standard deviation; ${ }^{\mathrm{b}}$ The numbers denotes illumination time (min). 
Table 4. Molecular weight of native and WLPL illuminated enzymes WT and TR. ${ }^{\mathrm{a}}$

\begin{tabular}{ccc}
\hline \multirow{2}{*}{$\begin{array}{c}\text { Enzyme illumination } \\
\text { time [min] }\end{array}$} & \multicolumn{2}{c}{ Enzyme molecular weight } \\
\cline { 2 - 3 } & $\mathrm{WT} \mathrm{M}_{\mathrm{w}} \times 10^{4}$ & $\mathrm{TR} \mathrm{M}_{\mathrm{w}} \times 10^{4}$ \\
\hline 0 & $3.62 \pm 0.25$ & $4.04 \pm 0.22$ \\
60 & $5.54 \pm .0 .31$ & $6.25 \pm 0.30$ \\
120 & $3.82 \pm 0.29$ & $4.67 \pm 0.29$ \\
\hline
\end{tabular}

${ }^{\mathrm{a}}$ Mean of three independent experiments \pm standard deviation.

Table 5. Evaluation of the secondary structure of protein chains of enzymes WT and TR prior to and after WLPL illumination for 60 and $120 \mathrm{~min}$.

\begin{tabular}{ccccccc}
\hline \multirow{2}{*}{ Structure } & \multicolumn{6}{c}{ Enzyme $^{\mathrm{a}}$} \\
\cline { 2 - 7 } & WT & WT60 & WT120 & TR & TR60 & TR120 \\
\hline Helix & 18.6 & 18.7 & 18.0 & 29.5 & 27.4 & 29.6 \\
Beta & 34.5 & 34.3 & 34.7 & 29.3 & 30.5 & 29.2 \\
Turn & 5.8 & 6.2 & 7.1 & 0.0 & 0.0 & 0.0 \\
Random & 41.0 & 40.8 & 40.2 & 41.2 & 42.1 & 41.2 \\
\hline
\end{tabular}

${ }^{\mathrm{a}}$ The numbers denotes illumination time.

In this work we decided to measure molecular weight of original and illuminated enzymes and, based on recorded CD spectra of the enzymes, evaluate their secondary conformation. Illumination with WLPL significantly changed molecular weight of the enzyme protein molecules. Molecular weight of original WT $\left(3.63 \times 10^{4}\right)$ and TR $\left(4.04 \times 10^{4}\right)$ enzymes increased significantly after 60 min illumination to $5.54 \times 10^{4}$ and $6.25 \times 10^{4}$ respectively. Further, 120 min illumination of the enzyme solutions led to decrease in the molecular weight of both WT120 $\left(3.82 \times 10^{4}\right)$ and TR120 $\left(4.67 \times 10^{4}\right)$ enzymes. Using Astra 4.73.04 software both, RI and LS detectors provided differential molar mass distribution. The differential molar mass distribution offered the amount of polymer (differential weight fraction) in a given molar mass interval [21]. Plots of differential weight fraction $v s$ molar mass for original and illuminated WT and TR enzymes are given in Figures 2(a) and (b), respectively. Clearly, illumination with WLPL changed the distribution of molecular weight of the enzyme WT protein chains.

Polydispersity of molecular weight of the original enzyme protein chains was much smaller than polydispersity observed for enzyme samples illuminated for 60 and $120 \mathrm{~min}$. Samples of illuminated enzymes contained fractions with protein chains with much lower and much higher molecular weight than these in original enzymes. It has been established that the cellulase complex of Trichoderma reesei contains at least three enzyme components that are both physically and enzymatically distinct and that all three components play essential roles in the overall process of converting cellulose to glucose.

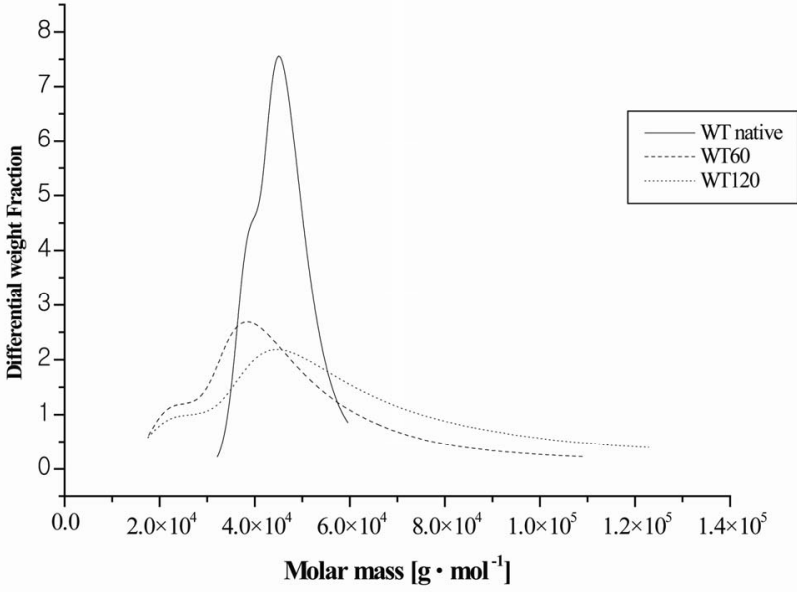

(a)

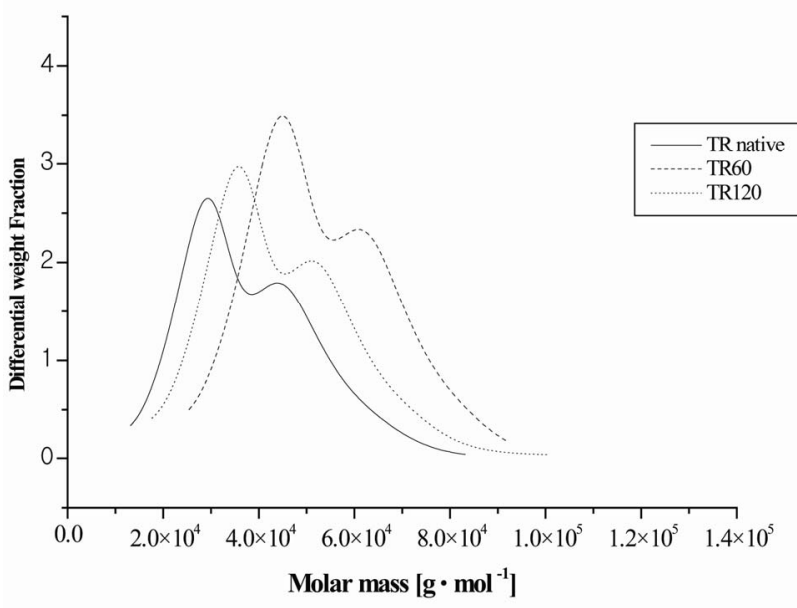

(b)

Figure 2. (a) Plot of Differential Weight Fraction vs Molar Mass for enzyme WT proteins prior to (WT native), and after illumination with WLPL for 60min (WT60) and 120 min (WT120); (b) Plot of Differential Weight Fraction vs Molar Mass for enzyme TR proteins prior to (TR native) and after illumination with WLPL for $60 \mathrm{~min}$ (TR60) and 120 min (TR 120).

Observed increase of polydispersity of molecular weight of protein chains in WLPL illuminated samples of enzyme WT could be result of light induced association between protein chains belonging to three different components of enzyme complex. One could expect that self association of protein molecules should lead to the products with molecular weight values periodic as multiples of a base molecular weight. However, random association, induced by WLPL, between three different protein chains led to the association products exhibiting broad range of molecular weight.

Data presented in Table 5 revealed that independently the illumination time the secondary structure of activated proteins in cellulases WT and TR did not change.

It has been shown [11] that pre-illumination of $\alpha$-amylase 
solutions with WLPL enhanced the starch hydrolysis rate and extent. Simultaneously, the illumination of $\alpha$-amylase led to significant changes in the secondary conformation of the enzyme protein molecule. It has been assumed that conformational changes in the enzyme protein structure were, at least partially, responsible for the observed enhancement of hydrolytic activity of pre-illuminated $\alpha$-amylase. Protein compositions of $\alpha$-amylase and cellulases WT and TR are entirely different. Amylase is a single chain glycoprotein of about 475 residues and molecular weight in the range 50,000 [22]. Cellulases WT and TR are complex of three physically distinct components [23]. Such differences in molecular structure between amylase and cellulases studied could explain lack of conformational changes in proteins of WLPL activated cellulases.

\section{Conclusions}

1) Stimulation with white linearly polarized light of two cellulases WT and TR isolated from Trichoderma reesei increases the enzyme specific activity of the microcrystalline cellulose digestion and rate constants of both stages of enzymatic hydrolysis of microcrystalline cellulose.

2) The WLPL stimulation of cellulases significantly influences molecular structure of cellulose chains in digested microcrystalline cellulose compared to these resulting from the hydrolysis with original enzyme.

3) Illumination of both WT and TR enzymes led to significant changes of molecular weight of enzyme protein chains, however, activation of enzymes with WLPL did not change enzyme protein secondary structure.

\section{Acknowledgements}

This work was financed by grant N N313 265936 from National Science Center, Poland.

\section{REFERENCES}

[1] K. Wickholm, E. Hult, P. Larsson, T. Iversen and H. Lennholm, "Quantification of Cellulose Forms in Complex Cellulose Materials: A Chemometric Model," Cellulose, Vol. 8, No. 2, 2001, pp. 139-148. doi:10.1023/A:1016700325434

[2] L. R. Lynd, "Overview and Evaluation of Fuel Ethanol from Cellulosic Biomass: Technology, Economics, the Environment, and Policy," Annual Review of Energy and the Environment, Vol. 21, 2001, pp. 403-465. doi:10.1146/annurev.energy.21.1.403

[3] L. R. Lynd, R. T. Elander and C. E. Wyman, "Likely Features and Costs of Mature Biomass Ethanol Technology," Applied Biochemistry and Biotechnology, Vol. 5758, 1996, pp. 741-761. doi:10.1007/BF02941755

[4] L. Laureano-Perez, F. Teymouri, H. Alizadeh and B. E.
Dale, "Understanding Factors That Limit Enzymatic Hydrolysis of Biomass," Applied Biochemistry and Biotechnology, Vol. 121, 1996, pp. 1081-1100.

[5] H. Hoeksema, S. Monstrey, K. Van Landuyt, Ph. Blondeel, P. Tonnard and A. Verpaele, "The Use of Polarised Light in the Treatment of Severely Burned Patients (Abstract)," 10th Congress of the International Society for Burn Injuries, Jerusalem, 1-6 November 1998, pp. 1-6.

[6] K. Depuydt, S. Monstrey and H. Hoeksma, "The Stimulating Effects of Polarized Light on Wound Healing and Avoiding Surgery in the Treatment of Deep Dermal Burn Wounds Using Polarized Light," 10th Annual Meeting of the European Association of Plastic Surgeons, Madrid, 21 May 1999, pp. 21-25.

[7] W. Vanscheidt, "The Effect of Polarized Light on Wound Healing," European Journal of Plastic Surgery, Vol. 24, No. 8, 2002, pp. 383-390. doi:10.1007/s00238-001-0306-z

[8] E. Bazso, Sz. Varju, P. Szego, K. Roza and P. Apai, “Application of Incoherent Wide Band Polarised Light to Promote Healing of Wounds," Central Research Institute for Physics, Budapest, 1982, pp. 121-130.

[9] W. Stegmann, "Behandlung des Ulcus Cruris mit Polarisiertem Licht," Phlebologie und Proktologie, Vol. 14, 1985, pp. 96-97.

[10] M. Fenyö, "Theoretical and Experimental Basis of Biostimulation," Optics \& Laser Technology, Vol. 16, 1984, pp. 209-215. doi:10.1016/0030-3992(84)90029-X

[11] M. Fiedorowicz and G. Chaczatrian, "Effect of Illumination with the Visible Polarized and Non-Polarized Light on $\alpha$-Amylolysis of Starches of Different Botanical Origin," Journal of Agricultural and Food Chemistry, Vol. 51, No. 26, 2003, pp.7815-7819. doi:10.1021/jf026202r

[12] A. Konieczna-Molenda, V. M. F. Lai, M. Fiedorowicz, G. Khachatryan and P. Tomasik, "Effect of Linearly Polarized Light upon Xylanase Activity," Biotechnology Progress, Vol. 24, No. 2, 2008, pp. 385-388. doi:10.1021/bp070394z

[13] A. Konieczna-Molenda, M. Fiedorowicz, W. Zhong and P. Tomasik, "Polarized Light-Stimulated Enzymatic Hydrolysis of Chitin and Chitosan," Carbohydrate Research, Vol. 343, No. 18, 2008, pp. 3117-3119. doi:10.1016/j.carres.2008.09.007

[14] M. Fiedorowicz, A. Konieczna-Molenda and G. Khachatryan, "Stimulation of Cyclodextrin-Glycosyltransferase (Turozyme) Activity by Illumination with Linearly Polarized Visible Light," Biotechnology Progress, Vol. 25, No. 1, 2009, pp. 147-150. doi:10.1002/btpr.90

[15] A. Konieczna-Molenda, M. Fiedorowicz and P. J. Tomasik, "Stimulation of Glucose Oxidase with White Linearly Polarized Light," Biotechnology Progress, Vol. 26, No. 2, 2010, pp. 393-396.

[16] G. L. Miller, "Use of Dinitrosalicylic Acid Reagent for Determination of Reducing Sugars," Analytical Chemistry, Vol. 31, No. 3, 1959, pp. 426-428. doi: $10.1021 / \mathrm{ac} 60147 \mathrm{a} 030$

[17] A. Dupont and G. Harrison, "Conformation and $\mathrm{dn} / \mathrm{dc}$ Determination of Cellulose in N,N-Dimethylacetamide 
Containing Lithium Chloride," Carbohydrate Polymers, Vol. 58, 2004, pp. 233-243.

doi:10.1016/j.carbpol.2004.07.016

[18] A. Dupont and G. Harrison, "Comparative Evaluation of Size-Exclusion Chromatography and Viscometry for the Characterisation of Cellulose," Journal of Chromatography A, Vol. 1026, No. 1, 2004, pp. 129-141. doi:10.1016/i.chroma.2003.11.002

[19] "Worthington Enzyme Manual," Worthington Biochemical Corporation, Lakewood, 1993.

[20] D. W. Schrott, "Differential Molecular Weight Distributions in High Performance Size Exclusion Chromatography" Journal of Liquid Chromatography \& Related Technologies, Vol. 16, No. 16, 1993, pp. 3371-3391. doi:10.1080/10826079308019695
[21] S. J. Horn, A. Sørbotten, B. Synstad, P. Sikorski, M. Sørlie, K. M. Vårum and V. G. H. Eijsink, "Endo/Exo Mechanism and Processivity of Family 18 Chitinases Produced by Serratia marcescens," FEBS Journal, Vol. 273, No. 3, 2006, pp. 491-503. doi:10.1111/j.1742-4658.2005.05079.x

[22] M. Granger, B. Abadie and G. Marchis-Mouren, "Limited Action of Trypsin on Porcine Pancreatic Amylase: Characterization of the Fragments," FEBS Letters, Vol. 56, No. 2, 1975, pp. 189-197. doi:10.1016/0014-5793(75)81088-X

[23] K. King and M. Vessal, "Enzymes of the Cellulase Complex," Advances in Chemistry, Vol. 95, 1969, pp. 130149. 